UNIVERSITY

OF DEBRECEN

FACULTY OF

Health

NYÍREGYHÁZA

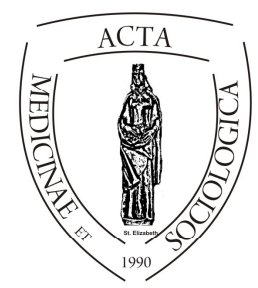

ACTA

MedSoc

Volume 8.

2017

\title{
NetWorking \\ Integráció a munka világába a személyes kapcsolathálózaton keresztül, holland- és Hollandiában letelepedett fiatal munka- vállalók esetében
}

\author{
Szabó Dóra
}

Debreceni Egyetem Egészségügyi Kar

\begin{abstract}
Absztrakt. A személyes kapcsolathálózatunk, kihat a dolgokhoz való általános hozzáállásunkra- attitüdünkre, viselkedésünkre, valamint a szociális a státusunkra. Természetesen a folyamat visszafelé is müködik: A személyiségünk által hozzánk hasonló barátokat-ismerösöket szerzünk, a barátainkon, kapcsolatainkon keresztül pedig nem csak materiális - és immateriális javak, hanem értékes további kapcsolatok válnak elérhetővé. Egy szerteágazó kapcsolati háló által előnyös társadalmi pozícióba kerülhetünk.

Granovetter (1974) óta tudjuk, hogy az erös kötéseink mellett, milyen nagy jelentősséggel bírnak a gyenge kötéseink is, akár egy munkahely-szerzés esetében is. De mi történik akkor, ha magunk mögött hagyva a családunkat, barátainkat, és a teljes addig felépített kapcsolathálózatunkat, és egy új országban próbálunk szerencsét? Lehetséges egyáltalán megfelelő munkát találni ezek nélkül az erős-és gyenge kötések nélkül? Hogyan zajlik a munkatalálás folyamata?

A kutatásomban két fókuszcsoportra koncentrálva keresem a választ a fenti kérdésekre: megvizsgáltam a személyes kapcsolathálózat szerepét a munkatalálás folyamatában holland, illetve Hollandiában letelepedett külföldi fiatalok esetében.
\end{abstract}


A lekérdezéshez nagy segítséget nyújtott a LUBBERS és MOLINA szerzőpáros (2007;2010) által már korábban használt PSN-map elkészítésére és interjúra épülö komplex módszer, aminek segitségével egy teljesebb képet kaphatunk a megkérdezettek kapcsolati hálójáról.

Kulcsszavak: Hollandia, személyes kapcsolathálózat, kapcsolathálózat- térkép, interjú, munkakeresés

\section{Abstract. NetWorking- Integration to the world of work through the Personal Social Network in cases of Dutch and settled employees in the Netherlands.}

The social network, especially our strong ties, have a large-scale influence on our attitude, behaviour, and social status, and the process is working other way around as well. Through our friends, next to getting material, and immaterial goods, valuable social connections are available, what can be very useful to have a good position in the society, with far-reaching social network. (BARABASI, 2011 ).

Since Granovetter (1974) we know, the importance of the weak ties, for instance in case of finding a job. But what is happening, if we move to a different country, and we leave all the friends, family, and our whole social network behind us? Is it possible to find a suitable job, without this strong and weak ties? What is the mechanism to integrate ourselves into the world of work?

In my research, I am focusing on the mechanism of finding a job in the Netherlands, in two different cases. I explore the role of social network in the process, of people they born in the Netherlands or they moved there from an other country.

The idea of analysing the social network of migrants, was born before my research, by Miranda Lubbers and José Luis Molina (LUBBERS-MOLINA, 2015). Their work gave me a huge amount of help by building up the structure of my analysis. I used the methods of their research, because with combining the network map with narrative interviews we can end up by a complex, comparative analysis, and the cross checking helps to quit the blind sports of each approach (HERZ, ANDREAS/PETERS, LUISA/TRUSCHAT, INGA, 2013). My research would like to be additional to this interesting topic.

Keywords: Netherlands, social network, network map, narrative interviews, finding a job

DOI: $10.19055 / \mathrm{ams} .2017 .8 / 24 / 9$

\section{Bevezetés}

A személyes kapcsolathálózatunk összetétele, kihat a dolgokhoz való általános hozzáállásunkra- attitüdünkre, viselkedésünkre, valamint a szociális státusunkra. Természetesen a folyamat visszafelé is müködik: a személyiségünk által hozzánk hasonló barátokat, ismerősöket szerzünk, a kapcsolatainkon keresztül pedig nem csak materiális - és immateriális javak, hanem értékes további kapcsolatok válnak elérhetővé. Egy szerteágazó kapcsolati háló által, ugyanakkor előnyös 
társadalmi pozícióba kerülhetünk. Aki eleve sok kapcsolattal rendelkezik, az egyszerübben vonz be új kapcsolatokat: így, ahogy Barabási (2013) írja: a gazdag gazdagabb lesz mondás ez esetben is helytálló. A kapcsolathálózatunk folyamatosan velünk együtt változik.

Granovetter óta tudjuk, hogy az erős kötéseink mellett, nagy jelentősséggel bírnak a gyenge kötéseink is. Fontos szerepet játszhatnak akár egy munkahely megszerzésében is (GRANOVETTER, 1974). De mi történik akkor, ha úgy döntünk, hogy magunk mögött hagyva a családunkat, barátainkat, valamint a teljes addig felépített kapcsolathálózatunkat, egy idegen országban próbálunk szerencsét? Lehetséges egyálatalán megfelelő munkát találni ezek nélkül az erős-és gyenge kötések nélkül? Hogyan zajlik a munkatalálás folyamata?

A kutatásomban két fókuszcsoporta koncentrálva keresem a választ a fenti kérdésekre: megvizsgáltam a személyes kapcsolathálózat ${ }^{l}$ szerepét a munkatalálás folyamatában holland, illetve Hollandiában letelepedett külföldi fiatalok esetében.

Jelen tanulmányban miután röviden áttekintem a társas kapcsolatok szerepének jelentőségét a társadalmi integrációban, tisztázom a társadalmi tőke- kapcsolati tőke közötti különbségeket, valamint definiálom a kutatásom során használt erősés gyenge kötések fogalmát, elsösorban a kutatásban használt módszer részletesebb ismertetésére fogok koncentrálni. A Lubbers és Molina (2007; 2010) által már korábban használt módszer ( $P S N$-térkép ${ }^{2}$ és interjú), komplexitásának köszönhetően, egy teljesebb képet kaphatunk a megkérdezettek kapcsolati hálójáról. Véleményem szerint a társas kapcsolatok vizsgálatával foglalkozó szakemberek számára érdekes lehet a fent említett módszer részletesebb megismerése, hiszen a kapott adatok által sokrétü információra tehetünk szert a résztvevők kapcsolathálózatáról, amit az interjú során kapott válaszok tovább bővítenek. Az érdeklődő, de a társadalom tudomány területén kevésbé jártas olvasóknak, szeretettel ajánlom a tanulmány lábjegyzetében található idegen szavak,- és kifejezések jegyzékét.

2016. tavaszán hat holland és hét Hollandiban élő, de nem holland résztvevő PSN- térképét sikerült elkészítenem, interjúval kiegészítve. A kapott eredmények részletesebb ismertetésére azonban egy következő tanulmány keretén belül fogok sort keríteni. Jelen tanulmányban a vizsgálati populáció és a módszertan részletesebb bemutatása után a kapott eredményeket csak röviden foglalom öszsze - mintegy helyzetjelentéssel szolgálva.

\footnotetext{
${ }^{1}$ Kapcsolati háló, kapcsolathálózat: a kapcsolati háló (network) nem más, mint a szereplök (egos; alters) és a közöttük lévő kapcsolatok, kötések (ties) összessége (Wasserman \&amp; Faust 1994; Huszti, 2015; Dávid-Huszti-Lukács, 2016)

${ }^{2}$ PSN: Personal Social Network. Személyes kapcsolathálózat. Lásd: Kapcsolati háló, kapcsolathálózat ${ }^{1}$
} 


\section{Elméleti áttekintés: A társas kapcsolatok szerepe}

\section{Társadalmi integráció}

A kapcsolatok jelentőségét, sokrétü funkcióit, elengedhetetlen szerepét a társadalmi integrációban ${ }^{3}$ különböző tudományok neves képviselői számtalanszor bebizonyították.

Durkheim, a társadalmi integráció feltételeit a közös hiedelmekben, érzésekben, normákban - a kollektív tudatban és a társadalom tagjait összekötő szolidaritásban találta meg. Úgy vélte, hogy a kollektív tudat és a kollektív célok hozhatják létre az integrációt, amelynek az erössége a kapcsolatok erösségével is mérhető (DURKHEIM, 1982; NAGY, 2009, http://1).

Marx a hiányzó integráció következményének tekintette az elidegenedést, Durkheim és Merton pedig a norma-válság kudarcához kapcsolta az anómiát (DURKHEIM, 1982; MERTON, 2002; NAGY, 2009, http://1).

Max Weber nevéhez kapcsolódnak a társadalmi cselekvés és társadalmi kapcsolatok fogalmai, amelyek integráló funkcióval is rendelkeznek (WEBER, 1987). Talcott Parsons a társadalmat rendszerként értelmezi, amelynek egyik funkciója az integráció, amely a társadalom múködőképességét, stabilitását is segíti (PARSONS, 1985). Habermas a szociális- és rendszerintegráció fogalmának ötvözésével és szétválasztásával (életvilág és rendszer) teremti meg az integráció fogalmának egy lehetséges értelmezési keretét, melyben a társadalmi integráción keresztül a társadalmi önazonosság valósulhat meg (HABERMAS, 1994; NAGY, 2009, http://1).

\section{Társadalmi tőke - Kapcsolati tőke}

Bourdieu 1983-as tőke- elméletében három- plusz-egy tőke- típust különböztetett meg egymástól: ezek a gazdasági, a kulturális és a társadalmi tőke, valamint az úgynevezett szimbolikus tőke, ami egyes tőkefajták egymásra történő átváltásának („rekonverziójának”) folyamatát jelenti (BOURDIEAU, 1987). A társadalmi tőke azokat az erőfeszítéseket foglalja magában, amelyeket az egyének a társadalmi kapcsolathálók kialakítása céljából fejtenek ki. A társadalmi tőke magánvagyon, amely révén az érintettek erősíthetik társadalmi státusukat, sőt hatalomra tehetnek szert (ORBÁN-SZÁNTÓ, 2007, http://2).

A társadalmi tőke tehát olyan erőforrás, ami egy adott csoporthoz való tartozáson alapul. A jelentősége akkor mutatkozik meg, amikor nagyjából azonos gazdasági,- és kulturális tőkével rendelkező egyének, lényegesen eltérő eredmé-

\footnotetext{
3 Integráció: Beilleszkedés; Integrálódás beilleszkedés, egyes részek egyesülése egy egésszé; összegeződés. (kislexikon.hu)
} 
nyeket érnek el, azáltal, hogy mennyire képesek mobilizálni a saját érdekükben egy tőke-erős csoport kapcsolati tőkéjét. Tehát a kapcsolatok révén olyan gazdasági tőkét mozgathat meg az egyén, amelyet egyébként nem birtokolna (BOURDIEAU, 1998; DÁVID, HUSZTI, LUKÁCS, 2016).

Coleman értelmezése szerint a társadalmi tőke személyek között létrejövő társadalmi intézmény, ami csökkenti az egyén céljai eléréséhez szükséges társadalmi költségeket. Coleman a társadalmi tökét a kapcsolathálózat milyenségével jellemzi (COLEMAN, 1988; DÁVID, HUSZTI, LUKÁCS, 2016).

Lin (2008) alapvető különbséget fogalmaz meg a társadalmi töke, és a kapcsolati tőke fogalma között. Értelmezése szerint a társadalmi tőke a kapcsolatokon keresztül elérhető, és mobilizálható erőforrásokat jelenti, míg a kapcsolati tőke a kapcsolati háló mennyiségi- és minőségi jellemzőit foglalja magába.

\section{Erős- és gyenge kötések ${ }^{4}$}

A kapcsolatok értelmezésének egyik legelterjedtebb terminusa az erös- és gyenge kötések fogalma.

Granovetter 1. a kölcsönhatások időtartama, 2. a kötések ${ }^{5}$ érzelmi intenzitása, intimitása és 3. a kölcsönösen nyújtott szolgáltatások jellege alapján különbözteti meg a gyenge- és az erős kötéseket egymástól (GRANOVETTER, 1982).

Az erős kötéseknek tekintett kapcsolatok a kapcsolati erőforrás-áramlás során megszerzett és birtokolt státus megőrzésében, míg a gyenge kötések a státusok megszerzésében játszanak szerepet (ANGELUSZ, TARDOS, 1991; GRANOVETTER, 1991; LIN, 1991).

Lin (2008) a társas kapcsolatok intenzitása és kölcsönössége szerint a társadalmi kötődés három típusát különbözteti meg, amelyet a következő táblázat segítségével teszek átláthatóvá (DÁVID, HUSZTI, LUKÁCS, 2016):

\footnotetext{
${ }^{4}$ Kapcsolat/ Kötés erőssége: a kötés erőssége (tie strength) azt mutatja meg, mennyire áll egy adott személyhez közel a másik. Az együtt töltött idő mennyisége, az érzelmi intenzitás, az intimitás, vagy másképpen bizalom, valamint a kölcsönös segítségnyújtás egyaránt meghatározzák (GRANOVETTER, 1973, DÁVID, HUSZTI, LUKÁCS, 2016).

${ }^{5}$ Kötés: A kapcsolathálózatban előforduló kapcsolatok. (Huszti, 2015)
} 


\begin{tabular}{|c|c|c|}
\hline „binding” & „bonding” & „bridging” \\
\hline $\begin{array}{l}\text { (az egyénhez legköze- } \\
\text { lebb álló kapcsolatok) }\end{array}$ & $\begin{array}{l}\text { (szintén viszony- } \\
\text { lag zárt, homo- } \\
\text { gén csoport) }\end{array}$ & (az egyéntöl a legtávolabb) \\
\hline $\begin{array}{l}\text { 1. homogenitas } \\
\text { (nem, kor, iskolai } \\
\text { végzettség, stb.) }\end{array}$ & $\begin{array}{l}\text { 1. homogenitas } \\
\text { (bizonyos } \\
\text { tekintetben) }\end{array}$ & 1. heterogenitas \\
\hline 2. intimitás & $\begin{array}{l}\text { 2. közösen birto- } \\
\text { kolják az } \\
\text { erőforrásokat }\end{array}$ & $\begin{array}{l}\text { 2. különböző társadalmi cso- } \\
\text { portokon átívelö, híd-szerü } \\
\text { kapcsolatok }\end{array}$ \\
\hline $\begin{array}{l}\text { 3. bizalom, } \\
\text { érzelmek, } \\
\text { kölcsönös } \\
\text { segítségnyújtás, } \\
\text { rendszeres és intenzív } \\
\text { kapcsolat }\end{array}$ & $\begin{array}{l}\text { 3. közösen birto- } \\
\text { koljak az infor- } \\
\text { mációt }\end{array}$ & $\begin{array}{l}\text { 3. összekapcsoljak az egyéne- } \\
\text { ket a tőlük távolabb lévőkkel, } \\
\text { akiket az erős kapcsolatok révén } \\
\text { különben nem tudnának elérni }\end{array}$ \\
\hline $\begin{array}{l}\text { 4. Granovetteri } \\
\text { erös kötések }\end{array}$ & $\begin{array}{l}\text { 4. erös kötések }+ \\
\text { gyenge kötések }\end{array}$ & 4. gyenge kötések \\
\hline $\begin{array}{l}\text { 5. szük családi } \\
\text { kapcsolatok, } \\
\text { a szülők, } \\
\text { gyermekek, há- } \\
\text { zas/élettársak, bizal- } \\
\text { mas barátok }\end{array}$ & $\begin{array}{l}\text { 5. kollégák, } \\
\text { haverok sport- } \\
\text { társak }\end{array}$ & 5. laza ismeretségek \\
\hline
\end{tabular}

1. táblázat. Binding-Bonding-Bridging, Forrás: Dávid, Huszti, Lukács (2016).

Lin elmélete szerint a gyenge, - és erős kapcsolatokat elkülöníthetjük az általuk áramoltatott erőforrások milyensége szerint is (LIN, 2008; DÁVID, HUSZTI, LUKÁCS, 2016).

Az erős kapcsolatok biztosítják az intimitás, stabilitás, és bizalom érzését az egyén számára, segítik őt a megküzdésben, és támogatják a nehéz élethelyzetekben, emellett pedig biztosítják a fizikai- és pszichés jól-léthez szükséges javakat. A gyenge kapcsolatoknak elsődleges funkciója a társadalmi távolságok áthidalása, a közvetítés, illetve az információ-csere (KAWACHI, 2006).

Elméleti feltételezések és empirikus tapasztalatok alapján is számtalanszor bebizonyosodott, hogy a legközelebbi (családi, bizalmas baráti) kapcsolatainkra jellemző a homofília (KON, 1977; BLAU, SCHWARZ, 1984 in SZABÓ, 2015). A hasonlóság-elv következményeként az erős kapcsolataink kevésbé képesek széleskörü erőforrások áramoltatására, és nagyobb a bezáródás esélye. A gyenge kötésekre jellemző heterogenitás következtében azonban, - bár ezek a kapcsolatok nem nyújtanak érzelmi biztonságot - különböző erőforrások válnak általuk 
elérhetővé, így segítve az egyen integrációját a többségi társadalomba (GRANOVETTER, 1973, 1974; ANGELUSZ, TARDOS, 1998; GYARMATI, 2009; DÁVID, HUSZTI, LUKÁCS, 2016).

Granovetter Getting a Job (1974) címü munkájában részletesebben is foglalkozott a gyenge kapcsolatok szerepével a munkaerő piaci integrációban. Granovetter egyik fő állítása, hogy bizonyos területeken a gyenge kötések bizonyulnak hatásukat tekintve erősebbeknek, így például nagyobb mértékben hozzájárulnak az állások megszerzéséhez, a jövedelmek meghatározásához. A fent említett munkájában bebizonyította, hogy a gyenge- kötésü személyes kapcsolatok voltak az elsődleges csatornák, amelyeken keresztül az egyének információkat szereztek a munkalehetőségekről és álláshoz jutottak. Ezek a kapcsolatok kollegiális, munkával összefüggő kapcsolatok voltak, és viszonylag ritkán (erős- kötésü) baráti vagy családi kapcsolatok (GRANOVETTER, 1974).

\section{Kutatási probléma felvázolása}

A fent említett neves szerzők munkái alátámasztják, hogy a hosszú évek alatt kialakult kapcsolathálózatunk mennyire fontos szerepet játszik a társadalmi integrációban, valamint különböző materiális-, és immateriális javakhoz való hozzáférésben. Amíg az erős kapcsolataink fontossága magától értetődő lehet, talán nem is gondolunk bele a futó ismertségeink, kollegiális, szomszédi viszonyaink funkcióiba, egészen addig, amíg el nem veszítjük őket.

A migráció ${ }^{6}$ kérdése- különösen az elmúlt évben, - de napjainkban is folyamatosan napirenden van.

A 2015-os migrációs válság felkészületlenül érte Magyarországot (illetve egész Európát). A magyar társadalomban döntően két radikális - politikailag befolyásolt- ellenpólus jelent meg: az egyik oldal állítása szerint a migrációs hullám kulturálisan, és személyes biztonság tekintetében is veszélyezteti az országot (kontinenst), a másik oldal szerint pedig, tulajdonképpen egy nem létező, politikailag generált problémáról beszélünk (JUHÁSZ, MOLNÁR, 2016, http://3).

Bár a migrációs hullám radikálisan, és speciális módon érintette hazánkat (2015. szeptember 23-án 10. 046 illegális bevándorló lépte át a határt (JUHÁSZ, MOLNÁR, 2016, http://3), Magyarország megmaradt tranzit-ország szerepben, hiszen a menekültek szignifikáns hányada nem szándékozott tartósan letelepedni (JUHÁSZ, MOLNÁR, 2016, http://3; TÁRKI, 2016).

\footnotetext{
${ }^{6}$ Migráció: lakóhely változtatás, költözés, vándorlás. (idegen-szavak.hu)
} 
Hazánknak a migráció másik arcával kell szembenéznie, ez pedig az emigráció $^{7}$ folyamata. Magyarországon jellemző tendencia, hogy a fiatal, magasan képzett generáció jelentős hányada elhagyja az országot, és külföldön próbál szerencsét. A statisztikák szerint az elsődleges célországok: Ausztria, az Egyesült Királyság, illetve Németország mellett a Hollandiába emigrálók 4\%-os aránya is jelentős (SEEMIG A SEEMIG, 2014, http://4; TÁRKI, 2016; HÁRS, 2016). A fenti statisztika alátámasztja a meggyőződésemet, miszerint érdemes foglalkozni a Hollandiába emigrált bevándorlók kapcsolati hálójának feltérképezésével, hiszen hazánk jelentős arányú kivándorlója már 2014-ben Hollandiát választotta célországként. Véleményem szerint a 4\%-os arány a jövőben emelkedni fog, a BREXIT, (2016) hatására pedig az Egyesült Királyság kevésbé lesz vonzó célország.

\section{Kutatási kérdések, hipotézisek}

Amíg a bizalmas (erős) kapcsolataink kielégítik a szeretet-bizalom-intimitás iránti igényünket, emellett pedig immateriális, - és materiális javakat biztosítanak számunkra, a gyenge kötések segítenek áthidalni a társadalmi távolságokat, heterogén voltuknak köszönhetően olyan eröforrásokhoz segítenek bennünket, amiket egyébként nehezen, vagy egyáltalán nem érnénk el.

Granovetter $(1973$; 1974) bebizonyította a gyenge kapcsolatok (kollegiális, futó ismertségek) szerepét a munka-találás folyamatában.

Társadalom tudományi alaptézis, hogy a társadalmi integráció egyik legfontosabb pillére a munka, hiszen a társadalmi hasznosság alapvető elvárásként és normaként jelenik meg, országtól függetlenül.

Ambivalens tény, hogy bár a társadalom kevesebb mint egy százaléka vallja magát idegenbarátnak hazánkban (TÁRKI, 2015), a külföldre költözők- külföldön munkát vállalók száma évröl-évre növekszik (SEEMIG A SEEMIG, 2014). Felmerül a kérdes, hogy - kissé kifordítva a statisztikákat-, hogyan sikerülhet integrálódnunk egy idegenekből álló társadalomba, ha kevesebb mint $1 \%$-unk idegen barát? És milyen a fogadatatás?

Előző kutatásomban (2015), a magyar es holland barátságok specifikumait vizsgáltam minőségi, és mennyiségi megközelítésben, és a 2005-ös ESS- statisztikákra hivatkozva, Svájc, Dánia, Izland, Svédország mellett Hollandiát a legelégedettebb országok között említettem, ahol megvan az alapvető anyagi biztonság, és a társadalmi integráció. Vajon a más országokból érkezettek is részesülnek ezekből a javakból? Milyen hátrányokkal indul az, aki hátra hagyja a teljes kapcsolathálózatát, erős- és gyenge kötéseit, és tiszta lappal kezd új életet egy idegen kultú-

\footnotetext{
${ }^{7}$ Emigráció: Kivándorlás, külföldre költözés. (idegen-szavak.hu)
} 
rában? Egyáltalán, miért kelünk útra? Hogyan alakul a kapcsolati halónk, és mennyire erősek az erős kapcsolataink, ha több ezer kilométer választ el bennünket egymástól? Lehetséges egyáltalán integrálódnunk a munka világába, illetve a többségi társadalomba ezek nélkül az erős-, és gyenge kötések nélkül?

\section{Kutatási módszer}

Ahhoz, hogy közelebb kerüljek a kutatási kérdéseim megválaszolásához két módszert egyesítettem, amelyet már Lubbers és Molina (2010) is sikerrel alkalmazott hasonló témában. A személyes kapcsolathálózat-térkép (Personal Social Network $\mathrm{Map}^{8}{ }^{8}$ elkészítésével, és egy kvalitatív interjú kérdéseivel sikeresen kiküszöbölhetőek a vakfoltok, és egy teljesebb képet kaphatunk a résztvevők networkjéről (LUBBERS, MOLINA, 2010).

$\mathrm{Az}$ általuk is alkalmazott módszertant, saját ötleteimmel kiegészítve, a kutatás A- részének első lépéseként, névgenerátor- módszert ${ }^{9}$ alkalmazva igyekeztem feltárni a résztvevők erős, - és gyenge kapcsolatait, amelynek kritériumait az olvasott szakirodalmakra (GRANOVETTER, 1973, 1974, 1983; LIN, 2008; DÁVID, HUSZTI, LUKÁCS, 2016) alapozva definiáltam. (A két fogalom : az erős,- és gyenge kötések elkülönítése kutatónként eltérő lehet. A saját definícióimat később részletesen is ismertetem.)

A továbbiakban a kutatásban résztvevők meghatározták a kapcsolat típusát (HOGAN, CARRASCO, WELLMAN, 2007), és egy általam alkotott szituáció-

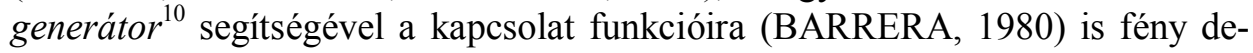
rült. Kíváncsi voltam, hogy mennyire valóságosak, a megjelölt funkciók, így a következő lépésben a résztvevők megjelölték, hogy ténylegesen eleget tett-e a megadott funkciónak az elmúlt 3 hónapon belül a szóbanforgó kapcsolat.

8 Personal Social Network-Map (PSN-Map): Személyes kapcsolathálózat- térkép, kapcsolathálózat grafikus ábrázolása.

9 Névgenerátor: módszerek alapvetően a társas támogató rendszer mérésére irányulnak. A névgenerátor alapesetben azt kéri a válaszadótól, hogy készítsen egy listát azokról a kapcsolatairól, amelyek eleget tesznek bizonyos, elöre megadott kritériumoknak, pl. erős kapcsolatok, barátok, stb. (Huszti, 2015)

${ }^{10}$ Szituációgenerátor: Névgenerátor típusú kérdőívek, amelyek azokban a szituációkban gyüjtenek neveket, melyeket a kutató előre megfogalmaz (és melyek kutatási témánként változóak lehetnek). ( Wellman, 1979, 2001a, 2001b; Fischer, 1982a, 1982b; Hogan, Carrasco and Wellman, 2007; Huszti, 2015) 
Ezután elkészítettük a résztvevők PSN-mapjét, vagyis személyes kapcsolathálózat térképét (Brandes és mtsi 2010; Lubbers-Molina 2007, 2010), amelyet nagy érdeklődéssel, és lelkesedéssel fogadott minden résztvevő.

A lekérdezés B- részében került sor az interjúra, amelyet néhány általános (demográfiai, és munkaviszonnyal kapcsolatos) kérdéssel indítottunk. Ezután néhány specifikus kérdés mentén kerestem a választ, többek között a migráció okaival, motivációival kapcsolatban. Kíváncsi voltam, hogy miért Hollandiára esett a résztvevők választása. Fontosnak tartottam megtudni, hogy mit dolgoznak jelenleg, milyen viszonyban áll ez az anyaországbeli ${ }^{11}$ munkájukkal, végzettségükkel, illetve a munkakeresés-találás folyamatára is kitértünk. Kíváncsi voltam, hogy a névgenerátor- során összegyüjtött alterek közül kinek volt szerepe a migrációs folyamatban, és kinek a munkaszerzés folyamatában. Szerepel -e a felsorolt személyek között olyan, akit a munkájuknak köszönhetően ismertek meg? (A teljes kérdéssor a mellékletben megtalálható.)

A kutatásom célja volt tehát, egyrészről felderíteni a Hollandiában letelepedett fiatal külföldi munkavállalók, és a holland fiatal munkavallók kapcsolathálózatát, hogy megvizsgáljam, a külföldi munkavállalóknak sikerült-e integrálódniuk a társadalomba azáltal, hogy megjelennek holland altere $^{12}$ a személyes kapcsolatháló- térképen. A kapcsolatháló megmutatja a kapcsolat erősségét (közelségét), és ellenőrizhetővé teszi, a kölcsönösséget a holland kitöltők PSN-jén keresztül.

Amennyiben találunk holland altereket a külföldiek kapcsolthálójában, az interjú kérdések mentén ellenőrizhetővé válik, hogy volt-e ezeknek a kapcsolatoknak szerepe a munka keresés-találás folyamatában, illetve kapcsolódnak-e valahogyan a munkához.

A kapcsolat-térkép további értékes információkkal is szolgál az otthonmaradtakkal, Hollandiában élő azonos nemzetiségúekkel, illetve más (harmadik) nemzetiségüekkel fenntartott kapcsolatokat illetően.

\section{Az alkalmazott módszer gyakorlati lépései}

A kutatásban való részvételhez szükséges feltételeket a következő táblázat foglalja össze:

11 Anyaország: Kivándorló népcsoportok eredeti hazája, ahonnan kivándoroltak. Pl. A Hollandiában élő magyaroknak: Magyarország.

${ }^{12}$ Alter: a vizsgált személyhez (ego) köthető mások. (Huszti, 2015) 


\begin{tabular}{|c|c|c|}
\hline & \multicolumn{2}{|l|}{ Résztvétel feltételei } \\
\hline & Nem Holland & Holland \\
\hline Nemzetiség & $\begin{array}{l}\text { Hollandián kívül született, és } \\
\text { nőtt fel, viszont jelenleg } \\
\text { Hollandiában él, min. egy } \\
\text { éve, max. tíz éve, és ez tervei } \\
\text { szerint nem fog megváltozni } \\
\text { az elkövetkezö egy évben. }\end{array}$ & $\begin{array}{l}\text { Hollandiában született, és } \\
\text { nött fel. }\end{array}$ \\
\hline Életkor & \multicolumn{2}{|c|}{ Maximum 35 éves. } \\
\hline Munkaviszony & \multicolumn{2}{|c|}{ Rendelkezik holland munkaviszonnyal. } \\
\hline Időkeret & \multicolumn{2}{|c|}{ Rendelkezik legalább 2,5 - 3 óra szabadidővel. } \\
\hline Nyelvtudás & \multicolumn{2}{|c|}{ Angol nyelv: szóbeli, és írásbeli kommunikáció. } \\
\hline
\end{tabular}

2. táblázat. Részvétel feltételei, saját szerk, 2017.

A lekérdezés elkezdéséhez szükséges tárgyi feltételek listája tételesen felsorolva megtalálható a mellékletben.

A lekérdezés két fő részből állt (A- és B rész). Az A- rész első lépéseként név, - illetve szituáció generátor segítségével a megkérdezettek különböző színü post-itekre összegyüjtötték a nagyon, és - valamelyest közeli kapcsolataikat, illetve meghatározták, hogy milyen típusú kapcsolatokról van szó, és mik ezeknek a kapcsolatoknak a fó funkciói.

Az erős és gyenge kapcsolatok értelmezésére nincs egyetlen általánosan elfogadott kritérium- rendszer. Elterjedt értelmezés, csak a családi kapcsolatokat erős kötésként definiálni, míg a baráti, és ismerősi kapcsolatokat gyenge kötésként (NAGY, 2009, http://3). A kutatás alanyai esetében nem tartottam ezt megfelelönek, hiszen többségük elveszítette a család fizikai közelségét. Feltételeztem, hogy egy ilyen élethelyzetben esetleg a bizalmas barátok vehették át a család helyétfunkcióit. A saját definícióm megalkotásához több szerző értelmezését is felhasználtam: segítségemre voltak a definíció megalkotásánál elsősorban Granovetter (1988), Lin (1991), Barrera (1980), Burt (1984), valamint a Lubbers és Molina (2007, 2010) szerzőpáros vonatkozó munkái.

Az említett szerzők tanulmányai mellett, a 2015-ben megjelent kutatásom erdeményeit is bevontam, amelyben a holland és magyar barátkozási szokásokat vizsgáltam. A megkérdezett magyar válaszadók a barátságaik legfontosabb kritáriumának a bizalmat (98\%), az öszinteséget (95\%), a jó beszélgetéseket (95\%), az egymással szembeni toleranciát ( 92\%), egymás segitését (92\%), és a kölcsönösséget ( 85\%) tartották. A megkérdezett hollandok körében szintén első helyen jelent meg a bizalom (84\%) fontossága, ezt követte a közös szórakozás (82\%), az öszinteség ( $81 \%)$, és a tolerancia (80\%) (SZABÓ, 2015). 
A kutatás során megadott kritérumok alapján, a legközelebbi kapcsolatainkban fontos a bizalom, az érzelmi támogatás, bármilyen problémával fordulhatunk ezekhez az emberekhez, nem viselünk álarcot előttük, adunk a véleményükre, és számítunk a szeretetükre, elfogadásukra, és szívesen töltjük velük a szabadidönket. Bizonyos szintü intim kapcsolatban állunk velük. Nem csak ök támogatnak bennünket, hanem mi is mellettük állunk, ha szükség van rá, tehát megjelenik a kapcsolatban a reciprocitas.

Csakúgy, mint a nagyon közeli, a valamelyest közeli kapcsolatok (gyenge kötések) felsorolásánál is fontos volt, hogy minden megadott kritériumnak feleljen meg az illető. Ezek a kapcsolatok egymás személyes és kölcsönös ismeretén, egymás elérhetöségén, illetve legalább egy közös tulajdonságon alapszanak. A kapcsolat több, mint egy egyszerü ismerösi viszony, viszont nem bizalmas, és nem túl közeli.

A kapcsolatok tipizálásához Hogan- Carrasco-Wellman- besorolását (2007) használtam. (Melléklet) Fontos volt, hogy ezen a ponton meg bővíthették a megkérdezettek mindkét listát, ha további alterek jutottak az eszükbe.

A támogatás típusának méréséhez szituáció-generátort használtam, a támogatás típusait pedig Manuel Barrera- Method of measuring social support (1980) című munkája alapján határoztam meg. Ehhez a hat különböző típusú szociális támogatáshoz (1. Anyagi támogatás, 2. Fizikai segítség, 3. Intim interakció, 4. Tanács, 5. Visszaigazolás, 6. Társas kapcsolatok) generáltam hat hétköznapi szituációt.

A kutatás A- részének második lépése volt a PSN-map, vagyis a személyes kapcsolathálózat- térkép elkészítése. Ehhez nagy segítséget nyújtott a DávidHuszti-Lukács szerzőhármas: Társas kapcsolatok jelentössége a társadalmi integrációban c. munkájának különösen az Egyén hagymahéj-szerü kapcsolati beágyazódásáról szóló fejezete. Az ego ${ }^{13}$ köré hagymahéj- szerủen rendeződnek a különböző társas kapcsolatok, és minél közelebb állnak az egyénhez ezek a kapcsolatok, annál erősebbek. Az első hagymahéj tehát az erös kötések, amelyet a szerzők a családra, bizalmasra, bizalmas barátra értenek. A második a gyenge kötések, amelyhez a barátokat, haverokat, jó ismerősöket sorolják. Ezután következnek a Közösségi, Civil, Szomszédi kapcsolatok, és vegül a Virtuális, Transzcendens kapcsolatok, amelybe azok a kapcsolatok tartoznak, amelynek alapja a közös identitás, és hovatartozás pl. lokális közösség, etnikum (DÁVID, HUSZTI, LUKÁCS, 2016).

${ }^{13}$ Ego: én; egyén (idegen-Szavak.hu); vizsgált személy (HUSZTI, 2015; WASSERMAN \&AMP; FAUST, 1994) lásd: kapcsolati háló 


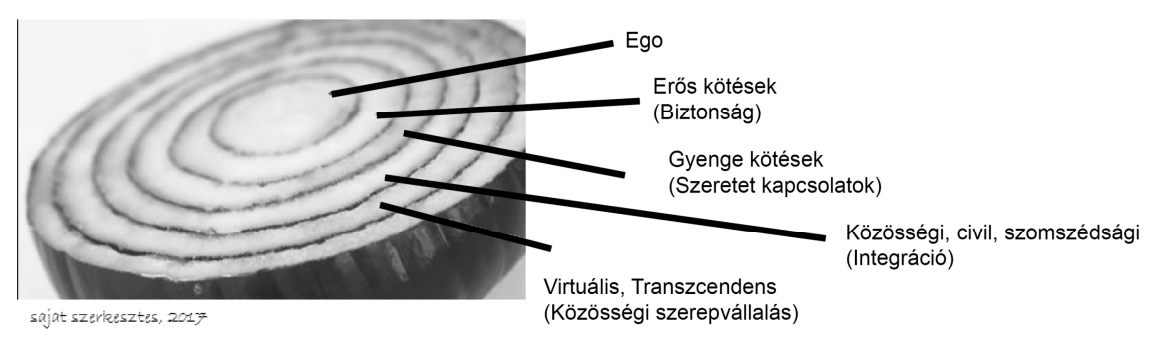

1. ábra. Hagymahéj-szerü kapcsolati beágyazódás.

Forrás: Dávid-Huszti-Lukács (2016).

$\mathrm{Az}$ általam is használt PSN-map elkészítéséhez Hogan-Carrasco és Wellman (2007) részletes instrukciókkal szolgál. A bevándorlók kapcsolathálózatának kutatásához Lubbers és Molina (2010) már korábban is alkalmazta a módszert. A network-térkép tehát egy keresztbe vágott hagymához hasonlítható, amely közepén az ego helyezkedik el. Négy kört rajzoltam az ego köré, viszont nem határoztam meg pontosan, hogy melyik körnek mi a jelentése, mint ahogyan a fenti ábrán láthatjuk.

A lap közepén elhelyezkedő ábrát horizontálisan, és vertikálisan is keresztbe vágtam, ezáltal tehát négy negyedre osztottam. Az egyszerüség kedvéért a lenti ábra szemlélteti, hogy néz ki a kapcsolthálózat-térkép a gyakorlatban.

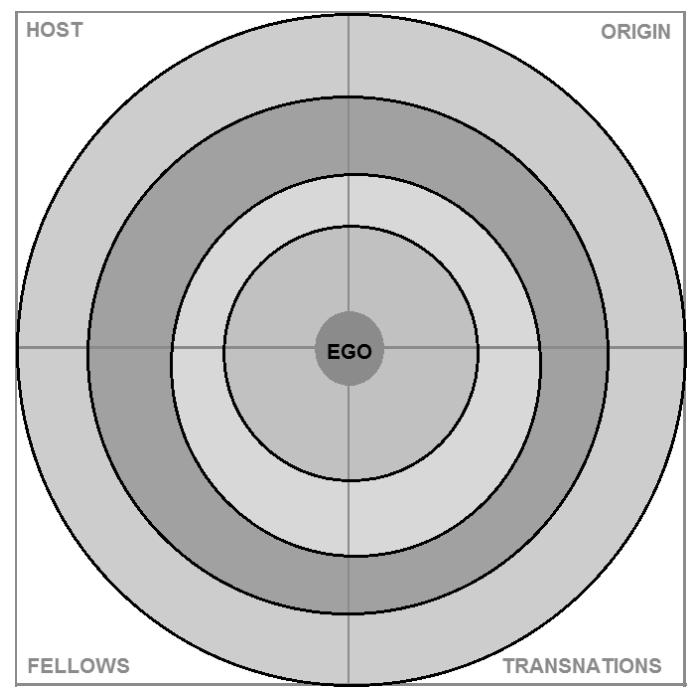

2.ábra. Kapcsolathálózat-térkép(PSN). 
A papír jobb- bal - alsó- és felső oldalán található kategóriák definíciója a következő (BRANDES, 2008 in DÁVID, HUSZTI, LUKÁCS, 2016) volt:

Host: Az új ország befogadó közege. Tehát azok a kapcsolatok, akik hollandok, és Hollandiában élnek. (Hollandiában élő hollandok.)

Origin: Kibocsájtó közeg. Azok a kapcsolatok, akik az anyaországban születtek, és jelenleg is ott élnek. (Otthoniak.)

Fellows: Hasonló kulturális közeg. Azok a kapcsolatok, akik az anyaországból származnak, és a befogadó országban élnek. (Sorstársak.)

Transnationals: Mindenki más. Azok a kapcsolatok, akik nem az anyaországból származnak, és nem is Hollandiából. Élhetnek Hollandiában, vagy bárhol máshol. (Egyéb nemzetközi kapcsolatok.)

A lekérdezés B-részét egy két-részből álló interjú alkotta. A feltett kérdésekre kapott válaszok értékes információkkal egészítették ki a kapcsolatháló -térkép által kapott információkat. Mind az általános, mind a konkrétabb kérdések megtalálhatóak a mellékletben. (Melléklet)

\section{Vizsgálati populáció, résztvevők}

A résztvevők bevonása hólabda- módszerrel történt, amelyet a saját kapcsolathálózatomon keresztül indítottam. A részvétel kritériuma volt, hogy az ego 35 évnél fiatalabb legyen, valamint rendelkezzen bejelentett holland lakcímmel, és munkaviszonnyal. Összesen 13 kapcsolathálózat-térképet, és interjút sikerült elkészítenem, a lekérdezés átlagosan 3-5 órát vett igénybe. A résztvevőket minden esetben olyan helyszínen fogadtam, ahol nyugodt, barátságos környezetet tudtam biztosítani, és nem volt sürgető időkorlát. A részvevők mindegyike felsőfokú végzettséggel rendelkezik, vagy egyetemista. Az átlagéletkor 28 év volt, a legfiatalabb résztvevő 19, a legidősebb 35 éves. Hat holland, két olasz, egy lengyel, egy magyar, egy román, egy német, valamint egy holland-izraeli nemzetiségü alkotta a vizsgálati populációt. A fiatalok mindegyike magasan kvalifikált, ketten fogorvosok, hatan mesterdiplomával rendelkeznek, hárman alapdiplomával, egyikük tanuló, és egy másikuk OKJ-s végzettséggel rendelkezik. 


\begin{tabular}{|c|c|c|c|c|c|c|c|}
\hline & $\begin{array}{c}\text { Holland } \\
\text { résztvevők }\end{array}$ & \multicolumn{3}{|c|}{ Külföldi résztvevők } & \multicolumn{3}{|c|}{ Összes résztvevő } \\
\hline $\mathbf{N}=$ & 6 & & 7 & & \multicolumn{3}{|c|}{$\mathrm{N}=13$} \\
\hline Átlag életkor & 28,5 év & \multicolumn{3}{|c|}{28,1 év } & \multicolumn{3}{|c|}{28,3 év } \\
\hline $\begin{array}{l}\text { Legfiatalabb } \\
\text { résztvevő }\end{array}$ & 24 éves & \multicolumn{3}{|c|}{19 éves } & \multicolumn{3}{|c|}{19 éves } \\
\hline $\begin{array}{l}\text { Legidősebb } \\
\text { résztvevő }\end{array}$ & 32 éves & \multicolumn{3}{|c|}{35 éves } & \multicolumn{3}{|c|}{35 éves } \\
\hline Nemzetiség & $\begin{array}{l}\text { Holland: } 46 \% \\
\text { Egyéb: } 54 \%\end{array}$ & $\begin{array}{l}\text { Olasz } \\
\text { Lengyel } \\
\text { Magyar } \\
\text { Román } \\
\text { Holland- } \\
\text { Izraeli } \\
\text { Német }\end{array}$ & $\begin{array}{l}2 \text { fó } \\
1 \text { fö } \\
1 \text { fö } \\
1 \text { fö } \\
1 \text { fö } \\
1 \text { fö }\end{array}$ & $\begin{array}{r}15 \% \\
7,70 \% \\
7,70 \% \\
7,70 \% \\
7,70 \% \\
7,70 \%\end{array}$ & $\begin{array}{l}\text { Holland } \\
\text { Olasz } \\
\text { Lengyel } \\
\text { Magyar } \\
\text { Román } \\
\text { Holland-Izraeli } \\
\text { Német }\end{array}$ & $\begin{array}{l}6 \text { fö } \\
2 \text { fö } \\
1 \text { fö } \\
1 \text { fö } \\
1 \text { fó } \\
1 \text { fó } \\
1 \text { fö }\end{array}$ & $\begin{array}{r}46 \% \\
15 \% \\
7,70 \% \\
7,70 \% \\
7,70 \% \\
7,70 \% \\
7,70 \%\end{array}$ \\
\hline $\begin{array}{l}\text { Férfi-Nő } \\
\text { arány }\end{array}$ & $67 \%-33 \%$ & \multicolumn{3}{|c|}{$43 \%-57 \%$} & \multicolumn{3}{|c|}{$54 \%-46 \%$} \\
\hline Végzettség & $\begin{array}{c}\text { DMD- } 1 \\
\text { MSc/Ma-2 } \\
\text { BSc/BA-2 } \\
\text { HAVO(OKJ) -1 }\end{array}$ & \multicolumn{3}{|c|}{$\begin{array}{c}\text { DMD-1 } \\
\text { MSc/MA- } 4 \\
\text { BSc/BA-1 } \\
\text { Student-1 }\end{array}$} & \multicolumn{3}{|c|}{$\begin{array}{c}\text { DMD-2 } \\
\text { MSc/MA- } 6 \\
\text { BSc/BA-3 } \\
\text { Student-1 } \\
\text { HAVO(OKJ)-1 }\end{array}$} \\
\hline
\end{tabular}

3. ábra. Vizsgálati populáció.

A kutatásom egyértelműen kvalitatív- jellegü. Tizenhárom személy nem túl sok, viszont a network elkészítése-analízise hosszadalmas, és nagy koncentrációt igényel mindkét oldalról. A kutatásom nem reprezentatív.

\section{Eredmények rövid ismertetése}

A kutatásom eddigi eredményei alátámasztották a hipotézisemet, miszerint a munka világába való belépéshez,- ami elengedhetetlen szereppel bír az integráció megvalósulásához- nélkülözhetetlenek a személyes kapcsolatok (GRANOVETTER, 1973, 1974, 1982). A tizenhárom résztvevőből tizen közvetlenül (ketten az erős -, és nyolcan a gyenge kötéseiken keresztül), hárman pedig közvetetten (közösségi oldal használatával) találtak munkát.

A migrációban legnagyobb motiváció a karrier, tanulás, jobb megélhetés lehetősége volt. Ezen kívül, hétből öt esetben a személyes kapcsolatrendszer is szerepet játszott a költözésben. A nem-holland megkérdezettek mindegyikének sikerült átlagosan hat héten belül munkahelyet találnia, a legrövidebb időszak egy hét, a leghosszabb időszak négy hónap volt. A külföldi munkavállalók esetében mindegyiküknek sikerült a saját végzettségének megfelelő munkahelyet 
találni, vagy ahol a tanulás volt az elsődleges motiváció (két esetben) bekerülni a kívánt szakra.

A bíztató adatok mellett azonban kirajzolódik, hogy a hét külföldi, és hat holland kapcsolathálózati térképen, négy külföldinél teljesen hiányoznak a HOSTkapcsolatok, egynél egy kapcsolatot találunk, a holland megkérdezettek esetében pedig három helyen teljesen hiányoznak, két helyen pedig egy-egy alter jelenik meg a TRANSNATIONALS kapcsolatoknál.

A tizenhárom megkérdezettből csupán ketten voltak, akiknél mind a négy kategóriában találtunk altereket. Itt jellemző, hogy amíg, a holland válaszadóknál minden kapcsolat-típus egy kategóriába tömörül (ORIGIN), addig ezeknél a megkérdezetteknél a különböző kapcsolat típusok szétoszlanak a négy kategóriában.

Szintén jellemző tendencia, hogy a holland megkérdezettek, átlagosan több altert említettek, mint a külföldi megkérdezettek.

A kapott eredmények elemzésekor kirajzolódott, hogy bár kiemelkedően fontos, hogy munkaviszonnyal rendelkezzünk, és ennek segítségével újra épüljön, bővüljön a kapcsolati hálónk, ahhoz, hogy ezek a munkahelyi kapcsolatok megjelenjenek az egyén PSN-térképén is (tehát említésre méltóan fontosak legyenek), szükséges, hogy beszeljük a vendég-ország anyanyelvét, attól függetlenül, hogy gond nélkül el lehet boldogulni angol-nyelvtudassal is.

A külföldiek esetében, amennyiben megjelent HOST-országbeni kapcsolat, azok szinte minden esetben munkával kapcsolatban álló (munka-általi, vagy munkához juttató) kapcsolatok voltak.

\section{Következtetések}

A magyarországi emigrációs folyamatok eredményeként évről-évre emelkedik a hazánkat elhagyó képzett fiatalok száma. A kutatásomban megkérdezett - nem csak magyar, hanem olasz, német, lengyel, román - fiatalok elsődleges motivációja a karrier építés, jobb megélhetés, magasabb bérek, akár a hazai problémák előli menekülést is reprezentálhatnák.

Minden külföldre költözőnek szembe kell néznie a ténnyel, hogy az addig felépített családi-baráti-ismerősi- iskolai- munkahelyi, és egyéb kapcsolatait hátrahagyva kell egy új kapcsolatrendszert kiépítenie, amin keresztül különböző egyéb kapcsolatokhoz, és javakhoz - pl. gazdasági, kulturális (Bourdieau,1983) férhet hozzá. 
A munkahely-találásban szintén szerepet játszanak a kapcsolatok (GRANOVETTER,1973, 1974, 1982) csakúgy, mint a munkahely a további kapcsolatok kiépítésében.

Egyértelműen kirajzolódik a külföldi résztvevők kapcsolat hálózatában, hogy bár több mint egy éve Hollandiában élnek, a kapcsolataik többsége továbbra is az ORIGIN kategóriában található. Bár az otthonmaradt kapcsolatok továbbra is kielégíthetnek bizonyos szociális funkciókat ( pl. anyagi támogatás, tanács, viszszaigazolás), bizonyos típusú támogatásokra nem képesek, egyszerủen a fizikai távolság következtében (fizikai segítség, intim interakció, társas kapcsolatok).

Mivel valóságos társas kapcsolatokra minden embernek alapvetően szüksége van (HABERMAS, 1994; DURKHEIM, 1982; MERTON, 2002) ennek köszönhetően jelennek meg új kapcsolatok elsősorban a TRANSNATIONALS, másodsorban a FELLOWS kategóriában. Ezen kapcsolatok müködését nem gátolják nyelvi akadályok, hiszen angolul, vagy anyanyelven folyhat a beszélgetés.

Az esetek többségében azonban hiányoznak a HOST kapcsolatok, ami negatív hatással van a többségi társadalomba történő integrációra.

\section{Összefoglalás, további kutatói kérdések}

Jelen tanulmányban a társas kapcsolatok fontosságának elméleti áttekintése után, részletesebben, gyakorlati megközelítésből mutattam be a kutatásom során használt módszert.

Felszínesen érintettem a kapott adatok tükrében elsősorban a migráció okait, a beilleszkedés- integráció problémáit, a munkatalálás folyamatát, illetve a kapcsolatok, és a munka viszonyát. Az elkészült PSN- térképek által lehetőségem volt megvizsgálni, hogy milyen arányban találunk altereket a négy kategóriában, melyik kategóriákban fordulnak jellemzően elö kapcsolatok, és hol hiányoznak. A holland és külföldi kapcsolati térképek, egymás tükörképei voltak, abban az értelemben, hogy kölcsönösen hiányoztak a holland (mint HOST) és nemholland (mint TRANSNATIONALS) kapcsolatok.

Sokrétủ további elemezési alternatívákat kínálnak a kapott adatok, amelyekből értékes információkat tudhatunk meg pl. az egok kapcsolathálózatának méretéröl, összetételéről. Az elkészült kapcsolathálózati térképek részletes- grafikus elemzése, valamint egymással és más hasonló témával foglalkozó kutatások eredményeivel történő összehasonlítása további érdekes adatokkal szolgál. 
Terveim között szerepel, esetleg egy év elteltével esetleg újra elkészíteni a PSNtérképeket, és összehasonlítani, hogy miben változott ezidő alatt a kapcsolati háló. Érdemes lenne részletesebben elemezni a különböző kapcsolatok funkcióit.

Bízom benne, hogy a jövőben lehetőségem lesz további résztvevők bevonásával bővíteni a vizsgálati populációt.

Véleményem szerint szükséges, és érdemes kiemelt figyelmet fordítani a személyes kapcsolatok megismerésének, illetve a bennük rejlő lehetőségeknek, hiszen a kapcsolati háló, illetve a munkaerőpiaci integráció koherenciája rengeteg lehetőséget kínál, nem csak országon belüli, de nemzetközi szinten is.

\section{Irodalomjegyzék}

1. Angelusz, R., Tardos R. (1998): A kapcsolathálózati erőforrások átrendeződésének tendenciái a kilencvenes években. In: Kolosi, T. et al. (szerk.) Társadalmi riport 1998. Budapest: TÁRKI. 237-256.

2. Barabási, A.L. (2013): Behálózva.- A hálózatok új tudománya. Budapest: Helikon Kiadó.

3. Barrera, M. (1980): A method for the assesment of social support net-works in community survey research. Connections 3 (3), 8-13

4. Blau, P.M., Schwarz, J.E. (1984): Crosscutting Social Circles: Testing the makorstuctural theory of intergroups relations. New York :Academic Press.

5. Bourdieu, P. (1983) Gazdasági tőke, kulturális tőke, társadalmi tőke. In: Angelusz, R. (szerk.) (1999) A társadalmi rétegződés komponensei. Budapest: Új Mandátum Könyvkiadó. 156-177.

6. Bourdieu, P. (1998; 1983). Gazdasági tőke, kulturális tőke, társadalmi tőke. Megj.: Lengyel - Szántó 1998.

7. Brandes, U., Lerner, J., Lubbers, M. J., McCarty, C., Molina, J. L. \& Nagel, U. (2010): Recognizing modes of acculturation in personal networks of migrants. Procedia Social and Behavioral Sciences, 4, 4-13.

8. Coleman, J. S. (1988): Social Capital in the Creation of Human Capital. American Journal of Sociology, 94, 95-120.

9. Dávid, B., Huszti, É., Lukács, Á. (2016) : Társas kapcsolatok jelentősége a társadalmi integrációban. Nyíregyháza: Acta Medicinae et Sociologica.

10. Durkheim, E. (1982): Az öngyilkosság. Budapest: Közgazdasági és Jogi Kiadó.

11. Granovetter, M. S. (1973): The Strenght of Weak Ties. American Journal of Sociology, 78(6): 1360-1380.

12. Granovetter, M. S. (1974): Getting a Job. Study of Contacts and Careers. Cambridge: Harvard University Press. 
13. Granovetter, M. S. (1982): A gyenge kötések ereje. A hálózatelmélet felülvizsgálata. In: Angelusz, R. \& Tardos, R. (szerk.) (1991) Társadalmak rejtett hálózata. Budapest: Magyar Közvéleménykutató Intézet. 371-400.

14. Gyarmati, Á. (2009) Hogyan verjünk hidat az idősekhez? Az ötven év fölöttiek kommunikációs és kapcsolathálózatának néhány jellemzője. Információs Társadalom, 9(4), 55-69.

15. Habermas, J. (1994): Válogatott tanulmányok. Budapest: Atlantisz.

16. Hárs, Á.(2016) : Elvándorlás, bevándorlás és a magyar munkaerőpiac. Jelenségek, hatások, lehetőségek, Budapest: TÁRKI.

17. Hogan, B., Carrasco, J.A., Wellman, B. (2007): Visualizing Personal Networks: Working with Participant-aided Sociograms

18. Huszti, É. (2015): Megismer-hetem: a személyes kapcsolathálózat feltárásának új formája : kapcsolati napló. Debrecen: Debreceni Egyetemi Kiadó.

19. Kon, I. (1977): A barátság. Budapest: Kossuth Könyvkiadó.

20. Lin, N. (2008): A network theory of social capital. In: Castiglione, D., van Deth, J. W. \& Wolleb, G. (szerk.) The Handbook of Social Capital. Oxford: Oxford University Press. 50-69.

21. Lubbers, M. J., Molina, J. L. \& McCarty, C. (2007): Personal Networks and Ethnic Identifications: The Case of Migrants in Spain. International Sociology, 22(6), 721-741.

22. Merton, R. K. (2002): Társadalomelmélet és társadalmi struktúra. Budapest: Osiris Kiadó.

23. M. J. Lubbers, J. 1. Molina, J. Lerner, U. Brandes, J. Ávila, C. McCarty (2010): Longitudinal analysis of personal networks. The case of Argentinean migrants in Spain in Social Networks, 32 (1), 91-104.

24. Parsons, T. (1985): A társadalmi rendszerről. Szociológiai Füzetek 45.

25. Szabó, D. ( 2016): Barátság-Magyar és holland egyetemista fiatalok barátkozási szokásainak vizsgálata: mennyiségi es minőségi szempontból. In Diaktudomany: Verzár Frigyes Szakkollégium hallgatóinak tudományos munkái 2015-16. 117-146.

26. Weber, M. (1987): Gazdaság és társadalom 1. Szociológiai kategóriatan. Budapest: Közgazdasági és Jogi Kiadó.

\section{Internetes hivatkozások:}

\section{http://}

1. http://www.rkk.hu/rkk/publications/phd/nagyt_ertekezes.pdf

(Nagy Terézia: Kötődések és kudarcok. A kapcsolatok és kapcsolati kudarcok szerepe az integrációban egy menekültek körében végzett terepmunka 
eredményei, Budapesti Corvinus Egyetem Szociológiai és Társadalompolitikai Intézet, 2009. Utoljára látogatva: 2017. Jan. 25.)

2. http://www.socialnetwork.hu/cikkek/OrbanSzanto2007.htm (Orbán Annamária és Szántó Zoltán (2005): Társadalmi tőke. In: Erdélyi Társadalom 2005/2. 55-70.o. Utoljára látogatva: 2017. Jan. 26. )

3. http://www.tarki.hu/hu/publications/SR/2016/13juhasz.pdf (Juhász Attila Molnár Csaba(2016): Magyarország sajátos helyzete az európai menekültválságban. In: TARKI. Utoljára látogatva: 2017. Jan. 26.)

4. https://www.ksh.hu/docs/szolgaltatasok/sajtoszoba/seemig_sajto_reszletes.pdf

5. (SEEMIG A SEEMIG - Managing Migration in South East Europe transznacionális együttmüködési projekt „Helyzetkép a magyarországi elvándorlásról" címü sajtótájékoztatójának sajtóanyaga Központi Statisztikai Hivatal, 2014. Október. Utoljára látogatva: 2017. Jan.20. )

\section{Adatbázisok:}

1. ESS, 2005

2. TÁRKI, 2015

3. TÁRKI, 2016

4. SEEMIG A SEEMIG, 2014

\section{Szabó Dóra}

2015-ben végzett szociális munka alapszakon, jelenleg pedig a Debreceni Egyetem Egészségügyi Karának SOWOSEC mesterszakos hallgatója. Debrecenben született, és nőtt fel, 2014-ben Amszterdamba költözött, és jelenleg is ott él. 